\title{
MODAL SIMBOLIK DALAM STRATEGI MEMBANGUN KEPERCAYAAN PELAKU ONLINESHOP
}

\author{
Fatwa Nurul Hakim ${ }^{1}$
}

\begin{abstract}
The development of e-commerce in Indonesia is very rapid, it is seen from the number of internet users has reached 93.4 million people in 2015, making Indonesia the potential to develop e-commerce. Based on Kemkominfo's information, at the end of 2015 the business value of e-commerce homeland was predicted to be around USD 18 billion. In 2020, the volume of e-commerce business in Indonesia is predicted to reach USD 130 billion with a growth rate of approximately 50 percent per year. More advanced ecommerce affects the pattern of buying and selling what was once conventional slowly turning to online trading. Online Business people in carrying out trading activities will not be separated from understanding symbols done in building trust. Building this trust can be reached through steps as follows: the testimony of satisfied buyers with the sold goods, both in terms of quality, price and size. There is also endorsed intervene to improve the online rating shop that is considered as an online shop that has been known and promote the product by advertisement. Buying and selling online is very closely on the exchange of symbols used to build trust.
\end{abstract}

Keywords: E-commerce, trust, economy

\begin{abstract}
ABSTRAK
Berkembangnya e-commerce di Indonesia sangat pesat, hal ini terlihat dari jumlah pengguna internet yang telah mencapai 93,4 juta orang pada tahun 2015, sehingga Indonesia sangat berpotensi untuk mengembangkan e-commerce. Berdasarkan Kemkominfo pada akhir tahun 2015, nilai bisnis e-commerce tanah air diprediksi sekitar USD 18 miliar. Pada tahun 2020, volume bisnis e-commerce di Indonesia diprediksi akan mencapai USD 130 miliar dengan angka pertumbuhan per tahun sekitar 50 persen (Kominfo.go.id, 2016). Semakin majunya e-commerce mempengaruhi pola jual beli yang dulunya konvensional secara perlahan beralih ke jual beli online Pelaku bisnis Online shop dalam melaksanakan kegiatan jual beli tidak akan lepas dari pemaknaan simbol yang dilakukan dalam membangun kepercayaan. Dalam membangun kepercayaan ini ditempuh dengan langkah-langkah sebagai berikut: adanya testimoni dari pembeli yang merasa puas dengan barang yang jual, baik dari segi kualitas, harga maupun ukuran. Ada juga campur tangan endorse untuk meningkatkan rating online shopnya sehingga dianggap sebagai online shop yang sudah terkenal dan mempromosikan produk dagangannya dalam hal ini iklan. Transaksi jual beli online ini sangat erat pada pertukaran simbol yang digunakan untuk membangun kepercayaan (trust).
\end{abstract}

Kata kunci: E-commerce, Kepercayaan dan Ekonomi

\footnotetext{
${ }^{1}$ Peneliti, Kementerian Sosial. email: fatwa.hakim@kemsos.go.id
} 


\section{PENDAHULUAN}

Dunia sedang beralih ke era digital. Hampir seluruh aktivitas dapat digitalisasikan melalui internet. Indonesia sebagai salah satu negara yang sedang berkembang turut menjadi bagian dalam perubahan global ini. Menurut Kementerian Komunikasi dan Informatika (Kemkominfo) pengguna internet di Indonesia hingga saat ini telah mencapai 82 juta orang. Dengan capaian tersebut, Indonesia berada pada peringkat ke- 8 di dunia. Dari jumlah pengguna internet tersebut, 80 persen di antaranya adalah remaja berusia 15-19 tahun (Kominfo.go.id, 2016).

Kegiatan ekonomi menjadi salah satu aktivitas yang sebagian besar sudah beralih ke digital. Di Indonesia sendiri perdagangan berbasis digital atau elektronik (e-commerce) sudah berkembang pesat. Menurut Republika.co.id bisnis daring di Indonesia pada tahun 2014 mencapai 12 miliar dolar AS dan diperkirakan akan terus tumbuh hingga mencapai 130 miliar dolar AS pada tahun 2020. Dengan jumlah pengguna internet yang telah mencapai 93,4 juta orang pada tahun 2015, pertumbuhan bisnis daring diperkirakan dapat mencapai 50 persen per tahun. Dengan begitu, Indonesia sangat berpotensi untuk mengembangkan $e$ - commerce. Berdasarkan Kemkominfo pada akhir tahun 2015, nilai bisnis $e$ commerce tanah air diprediksi sekitar USD 18 miliar. Pada tahun 2020, volume bisnis e-commerce di Indonesia diprediksi akan mencapai USD 130 miliar dengan angka pertumbuhan per tahun sekitar 50 persen (Kominfo.go.id, 2016).

Dengan pertumbuhan pengguna internet 19 persen pertahun, Indonesia diprediksi akan menjadi negara dengan ekonomi digital terbesar di Asia Tenggara. Hal tersebut terungkap dari riset yang dilakukan Google bersama Temasek untuk melihat peluang di Asia Tenggara dari enam negara dengan tema "e-conomy SEA: Unlocking the $\$ 200$ billion opportunity in Southeast Asia". Dalam riset ini disebutkan, pasar online Indonesia diprediksi akan meledak dalam 10 tahun, mencapai 81 miliar dollar AS sebelum 2025. Dari total tersebut, e-commerce menyumbang peranan sebesar 57 persen atau 46 miliar dollar AS (kompas.com, 2016).

Berkembangnya e-commerce di Indonesia salah satunya ditandai dengan banyak bermunculan situs jual beli online seperti blibli.com, lazada.co.id, zalora.co.id, berrybenka.com, salestock.com, mataharimall.com, 
olx.co.id, tokopedia.com, hingga bukalapak.com.

Pertama kali, perdagangan melalui sistem elekronik mulai dilakukan pada tahun 1994. Kegiatan ini bermula semenjak digunakannya banner di halaman-halaman website. Tak lama kemudian, sekitar tahun 2000, kegiatan promosi dan penjualan seperti ini memperlihatkan hasil yang luar biasa. Sehingga banyak perusahaan yang ikut memasang bannernya di internet. Yang lama kelamaan tercipta situs online shop dengan menyediakan barang ataupun jasa untuk diperjualbelikan.

Untuk skala yang lebih kecil banyak pelaku bisnis online yang memanfaatkan media sosial seperti Line, Instagram dan Facebook. Bidang fashion menjadi jenis produk yang banyak diperjualbelikan oleh pelaku online shop. Anak muda sebagai pengguna internet terbesar menjadi target konsumen nomor satu pelaku bisnis onlineshop.

Paper ini mengkaji tentang bagaimana para pelaku bisnis onlineshop khusus produk fashion dalam membentuk kepercayaan sebagai modal sosial dalam menarik pelanggan. Studi tentang modal sosial sudah menjadi kajian sosiologi ekonomi oleh para teoritisi (Coleman, Fukuyama, Bourdieu, Putnam, dalam
Field, 2014). Modal sosial sebagai salah satu modal utama individu atau kelompok dalam melakukan praktik sosial. Bourdieu dalam teori praktik sosial menjelaskan posisi modal (ekonomi, sosial, budaya) yang berakumulasi dengan habitus di dalam ranah atau arena akan menentukan kesuksesan praktik sosial. Begitu pula dengan pelaku onlineshop yang berusaha membangun kepercayaan melalui strategi promosi dan strategi membentuk brand produk untuk menarik pelanggan.

Bila kita menyusuri berbagai media sosial seperti facebook, instagram, line dan lain sebagainya banyak dijumpai iklan yang menawarkan berbagai model fashion. Dengan banyaknya model fashion, hal tersebut menjadi tantangan bagi pemilik bisnis toko online untuk dapat bersaing dengan toko online lainnya yang menawarkan jenis barang yang sama. Hal tersebut menjadikan faktor kepercayaan menjadi hal yang penting dalam menjalankan bisnis online shop ini. Sebab kepercayaan dengan pelanggan dapat membangun relasi antara pemilik bisnis online shop dengan konsumen. Sehingga dalam hubungan tersebut bisa memberikan keuntungan bagi pemilik online shop dengan konsumen.

$$
\text { Beberapa penelitian yang }
$$

membahas mengenai online shop atau toko online yang merebak di media sosial, 
antara lain menurut Hotlan Siagian dan Edwin Cahyono (2014) menemukan bahwa Website Quality terbukti berpengaruh terhadap Trust. Tampilan yang informatif, kesan keamanan, kemudahan dalam pengoperasian, kenyamanan dalam penggunaan, serta kualitas layanan yang baik dari website mampu meningkatkan kepercayaan konsumen terhadap kapabilitas atau kompetensi online shop dalam memberikan layanan. Ketika konsumen memiliki kepercayaan yang tinggi maka konsumen cenderung untuk mempertahankan kunjungan dan pembelian pada satu online shop.

Sebti Atul Awaliyah dan Saino (2013) dalam penelitiannya menemukan bahwa kualitas layanan berpengaruh secara simultan terhadap kepuasan pelanggan online di DKpop Shop. Variable yang berpengaruh pada kepuasan pelanggan pada DKpop Shop dalam penelitian ini adalah variable Efisiensi, Realibilitas, Daya Tanggap.

Jan Kho (2010) dalam penelitiannya menemukan bahwa website design memiliki pengaruh yang signifikan terhadap online shopping konsumen di Gramedia online. Hal ini menunjukkan bahwa semakin bervariasi dan menarik nya desain web semakin tinggi tingkat konsumen melakukan online shopping di
Gramedia Online. Disamping itu, reliability memiliki pengaruh yang signifikan terhadap online shopping konsumen di Gramedia online. Hal ini menunjukkan bahwa pelayanan yang sesuai dengan apa yang dijanjikan di website akan meningkatkan minat konsumen dalam melakukan online shopping di Gramedia Online. Sedangkan customer service memiliki pengaruh yang signifikan terhadap online shopping konsumen di Gramedia online. Hal ini menunjukkan bahwa pelayanan dan after sales yang baik akan meningkatkan minat konsumen dalam melakukan online shopping di Gramedia Online. Trust memiliki pengaruh yang signifikan terhadap online shopping konsumen di Gramedia online. Hal ini menunjukkan bahwa kepercayaan merupakan factor penting dalam bisnis online sehingga konsumen dapat percaya dalam melakukan online shopping di Gramedia Online.

Berdasarkan fakta-fakta tersebut diatas maka penulis tertarik mengangkat tema bisnis online dengan fokus bagaimana pemilik bisnis online shop membangun kepercayaan terhadap konsumen sehingga toko online yang dimiliki dapat mendapatkan keuntungan yang sesuai dengan target yang diinginkan 
dan juga mampu bersaing dalam ketatnya persaingan bisnis online shop.

METODE

Tulisan ini menggunakan pendekatan kualitatif. Dimana pengumpulan data diperoleh melalui data sekunder dengan telaah dokumen. Data dianalisis dengan model interaktif, melalui reduksi data, penyajian data, dan penarikan kesimpulan. Kajian yang ada didukung dengan beberapa kajian tentang kepercayaan dan modal simbolik dalam mengambangkan onlineshop. Fukuyama (2001) mengatakan bahwa modal sosial dibangun oleh kepercayaan antar individu, rasa saling percaya dibentuk dalam waktu yang tidak sebentar serta memerlukan proses-proses sosial yang berliku. Fukuyama melangkah lebih jauh lagi, mendefinisikan kepercayaan itu sendiri sebagai unsur dasar modal sosial yang merupakan kapabilitas yang muncul dari kepercayaan abadi ditengah-tengah masyarakat atau pada bagian tertentu dari masyarakat tersebut. Modal sosial terutama merefleksikan sistem nilai, khususnya kepercayaan sosial (Uslaner, 1999). Namun, Fukuyama sendiri mengklaim bahwa kepercayaan adalah dasar dari tatanan sosial komunitas tergantung kepada kepercayaan timbal balik dan tidak akan muncul secara spontan tanpanya (Fukuyama, 2001).

Modal simbolik menurut Bourdieu ini didefinisikan secara luas, mencakup pengakuan terhadap simbol-simbol tertentu yang mencerminkan kekuasaan, misalnya mobil, gelar, status sosial yang tinggi. Modal simbolik, yakni symbol kebudayaan yang dapat memperkuat kedudukan agen diantara agen yang lainnya atau dapat juga didefinisikan sebagai penghargaan yang telah didapatkan oleh aktor (Sjaf, 2014). Bourdieu melihat modal simbolik atau simbolic capital (seperti : harga diri, martabat, atensi) merupakan sumber kekuasaan yang krusial. Modal simbolik adalah setiap spesies modal yang dipandang melalui skema klasifikasi, yang ditanamkan secara sosial. Ketika pemilik modal simbolik mengguakan kekuatannya, ini akan berhadapan dengan agen yang memiliki kekuatan lebih lemah, dan karena itu si agen berusaha merubah tindakan-tindakannya. Maka, hal ini menunjukan terjadinya kekerasan simbolik. Contoh model simbolik ini dapat berupa pemilihan tempat tinggal, pemilihan tempat wisata, hobi, tempat makan dan sebagainya.

Jaringan sosial seperti yang telah dijelaskan di atas sangat erat hubungannya dengan hubungan sosial. Hubungan sosial 
dianggap sebagai syarat terciptanya jaringan sosial karena adanya interaksi dalam suatu masyarakat, misalkan saja pada jaringan ekonomi mikro. Saat ini telah marak bermunculan aktivitas ekonomi mikro yang mengandalkan sistem suatu jaringan yang terstruktur. Jaringan sosial mikro merupakan jaringan sosial yang terbentuk dari hubungan antar individu. Pada saat ini pesatnya perkembangan teknologi dan informasi merambah ke berbagai lapisan masyarakat. Hal ini tentunya mempermudah masyarakat dalam kegiatan ekonomi mikro, seperti bisnis media online sebagai penyedia pemasaran. Dengan interaksi menggunakan teknologi informasi bisa memudahkan pemasaran barang dan jasa melalui media online dan juga mampu memudahkan konsumen untuk mencari barang/jasa yang diinginkan.

\section{HASIL DAN PEMBAHASAN}

Dalam logika hukum ekonomi mencari keuntungan sebesar besarnya dengan pengeluaran biaya yang minimal menjadi orientasi pemilik modal dalam menjalankan transaksi jual beli. Hal ini dilakukan dengan berbagai upaya untuk menarik calon pembeli salah satunya dengan membangun modal sosial. Dalam transaksi jual beli online membangun kepercayaan kepada calon pembeli atau pelanggan menjadi salah satu modal utama kesuksesan bisnis.

Bila dalam transaksi jual beli konvensional kepercayaan dibangun secara langsung melalui interaksi yang terjadi langsung atau live antara penjual dan pembeli maka dalam jual beli online hal ini direduksi dalam transaksi via chat, messenger melalui media sosial seperti whatsapp, Blackberry Messenger, e-mail yang meminimalisir interaksi langsung tatap muka. Pada transaksi konvensional pembayaran yang dilakukan dengan tunai atau cash, cicilan dengan perjanjian lebih dulu atau ngutang.

Sedangkan pada transaksi jual beli online pembayaran dapat dilakukan dengan beberapa cara yaitu transfer melalui rekening atau kartu kredit, jasa rekening bersama (rekber), atau bisa melalui Cash On Delivery (COD). Proses yang demikian lebih sederhana dan menghemat waktu ini menjadi ciri khas yang membedakan dari transaksi jual beli online dengan jual beli konvensional. Dalam tabel berikut ini dijelaskan perbedaan antara transaksi online dan konvensional. 
Tabel 1. Perkembangan Jual Beli Konvensional Ke Online

\begin{tabular}{|l|l|l|}
\hline & \multicolumn{1}{|c|}{ Jual beli konvensional } & Jual beli online \\
\hline Transaksi & $\begin{array}{l}\text { Bertemu langsung penjual dan } \\
\text { pembeli }\end{array}$ & Tidak berinteraksi tatap muka \\
\hline Cara pembayaran & Tunai, ngutang, cicilan & Kartu kredit, Deposit, RekBer \\
\hline Cara promosi & Mulut ke mulut, baliho, spanduk, & Website, media sosial, \\
\hline Tempat usaha & $\begin{array}{l}\text { Ada fisik wujud tempat usaha } \\
\text { berbentuk kios, pasar, mall, } \\
\text { swalayan }\end{array}$ & Internet, media sosial \\
\hline $\begin{array}{l}\text { Pengambilan } \\
\text { barang }\end{array}$ & Sesaat setelah bayar ditempat & Delivery, Jasa kurir \\
\hline
\end{tabular}

Era transaksi jual beli online sekarang ini sangat erat pada pertukaran simbol yang digunakan untuk membangun kepercayaan (trust). Pada kondisi yang sudah parah simbol ini meluap hingga menghilangkan makna asli dari simbol yang akan disampaikan. Menurut Lyon (2000) persaingan simbolis dan manajemen sosial umumnya akan memberikan tekanan kepada konsumen yang tidak merasakan dan menyadari apa yang terjadi pada dirinya membentuk suatu sistem yang disebut Pierre Bourdieu (1984) sebagai seduction. Baudrillard lebih ekstrem dalam menyatakan logika konsumsi pada era digital ini bahwa fokus konsumsi tidak pada pemanfaatan nilai guna barang dan jasa namun terfokus pada produksi dan manipulasi sejumlah penanda sosial (Bagong, 2013).

Di Indonesia jual beli online khususnya fashion banyak sekali dilakukan oleh para pelaku usaha kecil menengah khususnya anak muda. Beberapa pelaku dengan modal relatif kecil memanfaatkan media sosial seperti instagram dan facebook, situs platform penyedia jasa jualbeli online seperti bukalapak.com, tokopedia.com, kaskus.co.id dan olx.co.id. Sedangkan pelaku dengan modal yang besar membuka bisnis online shop melalui situs internet, diantaranya adalah blibli.com, berrybenka.com, lazada.co.id, zalora.co.id, dan salestock.com. Bagi pelaku onlineshop skala kecil yang memanfaatkan platfofrm jasa jualbeli 
online membangun kepercayaan atau trust sebagai modal sosial dalam menarik calon pembeli tidaklah mudah. Berbagai usaha yang bermakna interaksionisme simbolik dilakukan dengan massif. Dari pengamatan yang telah dilakukan menemukan beberapa variasi strategi promosi dan strategi membentuk brand produk yang dilakukan pelaku online shop dalam yaitu sebagai berikut :

1. Membuat akun media sosial dengan follower yang jumlahnya banyak dari ratusan hingga ribuan. Hal ini kerap dilakukan sebagai upaya yang efektif dalam mempromosikan produknya dapat dilihat oleh banyak orang.

2. Endorsement produk kepada artis atau seniman. Endorse adalah meminta dukungan dari para artis dengan cara para pemilik usaha online shop tersebut memberikan barang dagangan atau produk yang mereka jual kepada artis yang mau mereka "endorse" secara gratis dengan imbalan balik sang artis nantinya mengunggah foto pribadi mereka dengan barang/produk pemberian dari online shop tersebut. Keuntungan dari endorse pemilik online shop pastinya sebagai sarana iklan dengan model artis yang telah mereka endorse dimana nantinya diharapkan dengan meng-endorse artis tersebut bisa meningkatkan penjualan produk yang mereka jual. Dan keuntungan sang artis atau orang yang diminta untuk mereka endorse, mereka mendapatkan dan menggunakan barang produk artis dari online shop tersebut.

3. Menggunakan foto artis atau model sebagai bio power dalam memamerkan produk.

4. Memberikan testimoni dari pelanggan yang sebelumnya sudah membeli produk.

5. Membangun reputasi penjual, pada beberapa situs online seperti tokopedia, bukalapak, atau kaskus penjual dapat memperoleh reputasi best seller atau recommended seller dengan mendapat respon balik dari konsumen. Salah satu contoh situs online yang banyak menggunakan reputasi pada penjual adalah kaskus.co.id. Kaskus merupakan situs forum yang memberikan ruang bagi pelaku bisnis online berupa forum jual beli kaskus. Berikut contoh dari reputasi penjual yang ada di kaskus.co.id.

Berbagai upaya tersebut sebelumnya merupakan strategi pelaku online shop dalam mempromosikan produk dagangannya dalam hal ini iklan. Dalam perkembangan masyarakat post-modern iklan merupakan salah satu kendaraan 
simulasi. Di era postmodern iklan mampu mengeksploitasi nilai guna dengan nilai tukar yang semu, dengan serangkaian image untuk menyebarkan benda-benda ke konsumen (Bagong, 2015). Dalam konteks diatas perilaku endorsment, testimoni, menciptakan follower, membangun reputasi merupakan modal simbolik yang dijelaskan oleh Bourdieu sebagai simbol kebudayaan yang diakui oleh konsumen. Simbol-simbol tersebut dinilai oleh konsumen sebagai penjual yang terpercaya sehingga membuat pelanggan tertarik.

\section{SIMPULAN}

Pelaku bisnis Online shop dalam melaksanakan kegiatan jual beli tidak akan lepas dari pemaknaan simbol yang dilakukan dalam membangun kepercayaan. Dalam membangun kepercayaan ini ditempuh dengan langkah-langkah sebagai berikut: adanya testimoni dari pembeli yang merasa puas dengan barang yang jual, baik dari segi kualitas, harga maupun ukuran. Ada juga campur tangan endorse untuk meningkatkan rating online shopnya sehingga dianggap sebagai online shop yang sudah terkenal dan mempromosikan produk dagangannya dalam hal ini iklan Transaksi jual beli online ini sangat erat pada pertukaran simbol yang digunakan untuk membangun kepercayaan (trust).

Fenomena yang terjadi pada online shop tersebut merupakan makna simbol atau modal simbol dimana testimoni dari pembeli serta banyaknya followers dari akun online shop tersebut dianggap simbol untuk mendongkrak kepercayaan terhadap pembeli lain yang mengunjungi onliine shopnya, kemudian endorse dari artis-artis untuk menciptakan ketertarikan dari pembeli. Artis dianggap sebagai pemaknaan simbol untuk menciptakan popularitas dari bisnis online shopnya. Proses jual beli pada bisnis online shop merupakan simbol-simbol untuk membangun kepercayaan pada pembeli untuk dapat bersaing dengan penjual konvensional.

\section{DAFTAR PUSTAKA}

Awaliyah, Sebti Atul dan Saino. 2013. Pengaruh Kualitas Layanan Terhadap Kepuasan Pelanggan Online (Studi Pada Dkpop Shop),http://id.portalgaruda.org diakses pada 16 September 2015.

Coleman S. James. 2008. Dasar-dasar teori social. Bandung: Nwa dua.

Jan Kho. 2010. Analisis Pengaruh Websitedesign, Reliability, Customer Service, Dan Trust Terhadap Online Shopping Pada Toko Gramedia Online 
http://id.portalgaruda.org diakses pada 16 September 2015.

John, Field. 2011. Modal Sosial. Kreasi Wacana. Yogyakarta

Lubis, Akhyar Yusuf. 2014. Postmodernisme: Teori dan Metode. Jakarta. PT. Rajawali Pers.

Siagian, Hotlan dan Cahyono, Edwin. 2014. Analisis Website Quality, Trust Dan Loyalty Pelanggan Online Shop http://id.portalgaruda.org diakses pada 16 September 2015.

Sjaf, Sofyan. 2014. Politik Etnik: Dinamika Politik Lokal Kendari. Jakarta: Buku Obor

Soedjatmiko, Haryanto. 2008. Saya Berbelanja, Maka Saya Ada. Yogyakarta: Jalasutra

Supriono, Agus. 2009. Coorperative Learning Teori Apliksi Palken. Yokyakarta: Pustaka Pelajar

Suyanto, Bagong. 2013. Sosiologi Ekonomi: Kapitalisme dan Konsumsi di Era Masyarakat Post-Modernisme. Jakarta: Kencana Prenadamedia Grup

Field, Jhon. 2014. Modal Sosial. Yogyakarta: Kreasi Wacana. 